\title{
Medikamentell profylakse ved migrene
}

\author{
Forebyggende behandling bør tilbys flere migrenepasienter enn i dag, og primærleger bør kjenne indikasjo- \\ nen og kunne administrere behandlingen. I utprøvningen er det viktig med langsom opptrapping, høye nok \\ doser og tilstrekkelig lang utprøvningstid. Pasienten må føre hodepinedagbok og gis realistiske forventninger \\ til effekt. De som har store plager bør få tilbud om å prøve minst tre ulike medikamenter.
}

Se også kunnskapsprøve på www.tidsskriftet.no/quiz

\author{
Lars Jacob Stovner \\ lars.stovner@ntnu.no \\ Erling Tronvik \\ Knut Hagen \\ Nasjonalt kompetansesenter for hodepine \\ Institutt for nevromedisin \\ Det medisinske fakultet \\ Norges teknisk-naturvitenskapelige universitet \\ og \\ Avdeling for nevrologi og klinisk nevrofysiologi \\ St. Olavs hospital
}

Rundt $12 \%$ av befolkningen har migrene (1). Mange pasienter har hyppige anfall som i betydelig grad går utover livskvalitet, funksjonsevne, familie og jobb. Som anfallsforebyggende tiltak bør man først søke å kartlegge og eliminere anfallsutløsende faktorer, redusere fysiske og psykiske belastninger og gi generelle råd om sunnere livsstil. Ofte vil også medikamentell profylakse være indisert. Studier tyder på at $25 \%$ av alle med migrene oppfyller kriteriene for slik behandling, men det er en mye mindre andel som faktisk bruker den (2). Spesialisthelsetjenesten vil alene ikke kunne håndtere migrene som folkehelseproblem, og primærlegen må derfor kjenne til indikasjonene og prinsippene for medikamentell profylakse.

Artikkelen er basert på de europeiske retningslinjene for migrenebehandling (3), forfatternes kliniske erfaring samt litteraturgjennomgang i forbindelse med egne publikasjoner innen feltet.

\section{Indikasjon}

De europeiske retningslinjene for behandling av migrene angir at profylakse bør overveies når (3):

- hodepinen påvirker livskvalitet, arbeidsevne eller skolegang i betydelig grad

- det er to eller flere anfall i måneden

- effekten av akuttbehandling er utilfredsstillende

- det er lange og besværlige auraepisoder

Kontraindikasjoner eller bivirkninger av anfallsbehandling, deriblant faren for å utvikle medikamentoverforbrukshodepine, bør også tas med i betraktningen.

Migrenediagnosen stilles $\mathrm{i}$ henhold til ICHD-2-kriteriene (4), med vekt på anfallsvarighet (4-72 timer ubehandlet), ledsagerfenomener (kvalme eller oppkast, lys- og lydskyhet) og smertekarakteristika (ensidig, pulserende, moderat til kraftig smerte som forverres ved moderat bevegelse). Mange pasienter med hyppig migrene har i tillegg spenningshodepine. Dette kan tilsløre diagnosen slik at de ikke får tilbud om profylakse.

Hvis pasienten har medikamentoverforbrukshodepine, anbefales vanligvis avvenning fra anfallsmedisiner før start av profylakse. Noen ganger vil dette gjøre at anfallshyppigheten går ned så mye at forebygging blir unødvendig. Ofte vil medikamentell profylakse likevel være indisert, både når anfallene fortsatt er besværlige og for å unngå tilbakefall til medikamentoverforbrukshodepine. For øvrig kan forebyggende medisiner være gunstig ved denne tilstanden selv om man ikke har gjennomført avvenning først (5).

\section{Utprøvning}

Pasienten bør føre hodepinedagbok i minst en måned før start av forebyggende behandling. Dette dels for å bekrefte indikasjonen og utelukke medikamentoverforbrukshodepine, og dels som grunnlag for å evaluere effekten. For å få et godt resultat er det viktig å informere og diskutere med pasienten hvorfor man bør forsøke medikamentell forebygging. Pasienten må skjønne at migrene er en kronisk sykdom selv om den manifesterer seg i enkeltstående anfall, og at det derfor er bedre å bruke faste medisiner som er beregnet til å tas daglig over lange perioder fremfor å ta anfallsmedisiner hyppig. Man må også forberede pasienten på bivirkninger, men at disse ofte kan gi seg etter hvert. Dessuten må vedkommende gis en realistisk forventning av hva man kan oppnå. Fullstendig anfallsfrihet er sjelden. Vanligvis bør man være fornøyd dersom dagboken viser en halvering av anfallshyppighet over en tremånedersperiode uten altfor sjenerende bivirkninger (3).

Ved utprøvning bør pasienten stå på antatt effektiv dose $\mathrm{i}$ minst to måneder før man evaluerer effekten. For å unngå at bivirkninger begrenser bruken bør opptrapping av dose skje langsomt. Mange migrenepasienter er antakelig berøvet muligheten for god anfallsprofylakse fordi de har brukt forebyggende medisin i for lav dose, i for kort tid, eller fordi de fikk bivirkninger de ikke var forberedt på. Dessuten bør man understreke viktigheten av at medisinene tas hver dag, idet uteglemmelse kan føre til anfall.

\section{Aktuelle medikamenter}

Tabell 1 oppsummerer de aktuelle perorale medikamentene. Tabellen baserer seg i stor grad på de europeiske retningslinjene, der man har gradert anbefalingen (A-C) etter vitenskapelig kunnskapsgrunnlag (3). Bare medikamenter som er tilgjengelig på vanlig resept i Norge er tatt med i tabellen.

Betablokkere har lenge vært førstevalg som migreneprofylakse. Kunnskapsgrunnlaget er best for propranolol og metoprolol, og disse bør brukes i depotformulering. Mens effektiv dose av propanolol kan variere svært fra individ til individ på grunn av stor førstepassasjemetabolisme i leveren, har metoprolol en mer forutsigbar farmako-

\section{Hovedbudskap}

- Flere migrenepasienter bør få tilbud om forebyggende behandling

- Behandling kan startes og følges opp i primærhelsetjenesten

- Pasientene bør føre hodepinedagbok, gis realistiske forventninger og være innstilt på langvarig utprøvning

- Ved valg av medikament bør det tas hensyn til bivirkninger og kontraindikasjoner samt eventuell komorbiditet hos pasienten 
Tabell 1 Perorale migreneforebyggende medikamenter

\begin{tabular}{|c|c|c|c|c|c|}
\hline Medikament & Anbefaling ${ }^{1}$ & $\begin{array}{l}\text { Døgndose } \\
\text { (mg) }\end{array}$ & Tilleggsindikasjon & Kontraindikasjoner & Vanlige bivirkninger \\
\hline Propranolol & A & $40-240$ & \multirow[t]{2}{*}{$\begin{array}{l}\text { Hypertensjon, tremor, } \\
\text { takykardi }\end{array}$} & \multirow[t]{2}{*}{$\begin{array}{l}\text { Astma, hjerteblokk, } \\
\text { diabetes }\end{array}$} & \multirow{2}{*}{$\begin{array}{l}\text { Ortostatisme, bradykardi, asteni, søvn- } \\
\text { vansker/mareritt, kalde ekstremiteter, } \\
\text { impotens }\end{array}$} \\
\hline Metoprolol & A & $50-200$ & & & \\
\hline Valproat & A & $500-1800$ & $\begin{array}{l}\text { Epilepsi, stemnings- } \\
\text { labilitet }\end{array}$ & $\begin{array}{l}\text { Leversykdom, koagula- } \\
\text { sjonsforstyrrelse }\end{array}$ & $\begin{array}{l}\text { Levertoksisitet, polycystisk ovariesyn- } \\
\text { drom, tretthet, vektøkning, håravfall }\end{array}$ \\
\hline Topiramat & A & $25-100$ & Epilepsi, overvekt & & $\begin{array}{l}\text { Prikking i hender og føtter, smaks- } \\
\text { endringer, vekttap, glemskhet, depre- } \\
\text { sjon, synsproblemer, nyrestein }\end{array}$ \\
\hline Amitriptylin & B & $50-150$ & $\begin{array}{l}\text { Depresjon, søvn- } \\
\text { vansker, fibromyalgi }\end{array}$ & $\begin{array}{l}\text { Trangvinkel-glaukom, } \\
\text { arytmier, monoamino- } \\
\text { oksidasehemmere }\end{array}$ & Tretthet, munntørrhet, urinretensjon \\
\hline Gabapentin & C & $1200-1600$ & $\begin{array}{l}\text { Epilepsi, nevrogene } \\
\text { smerter }\end{array}$ & & $\begin{array}{l}\text { Tretthet, psykiske endringer, syns- } \\
\text { forstyrrelser }\end{array}$ \\
\hline Lisinopril & C & 20 & \multirow{2}{*}{$\begin{array}{l}\text { Hypertensjon, hjerte- } \\
\text { svikt }\end{array}$} & \multirow[t]{2}{*}{ Angionevrotisk ødem } & Ortostatisme, tørrhoste, nyreskade \\
\hline Kandesartan & C & 16 & & & Ortostatisme, nyreskade \\
\hline
\end{tabular}

kinetikk. Kontraindikasjonene er mange og begrenser bruken.

For de to antiepileptiske medikamentene valproat og topiramat er det også godt kunnskapsgrunnlag (3). Valproat kan med fordel gis som depotformulering på 900-1200 mg daglig, fordelt på to doser. Levertoksisitet er en svært sjelden, men potensielt fatal bivirkning, og valproat må derfor ikke gis til pasienter med kjent leversykdom. Ved langtidsbruk må man overvåke leverfunksjonen med blodprøver, helst før start og regelmessig i løpet av de første seks månedene. Topiramat er grundig utprøvd på migrenepasienter. Bivirkninger er vanlige, men begrenses med meget langsom opptrapping. Det er vanlig å starte med $25 \mathrm{mg} \times 1$, med opptrapping hver annen uke til $50 \mathrm{mg} \times 2$ i løpet av seks uker. Hos enkelte pasienter kan daglig dose økes til 400 mg før effekt kommer og uten at det kommer bivirkninger. Vekttap på noen få kilo er vanlig, noe som gjør at mange synes dette medikamentet er attraktivt.

Flere medikamenter har et noe lavere kunnskapsgrunnlag enn de ovennevnte. Gabapentin kan forsøkes ved migrene, og har vanligvis få bivirkninger. Blant de trisykliske antidepressivene er det amitryptilin som har best dokumentasjon (3). For migrene vil man vanligvis ikke gå høyere enn $50-70 \mathrm{mg}$ daglig, og en dose helt ned i $10 \mathrm{mg}$ kan være effektiv. For å unngå plagsom tretthet bør medisinen tas et par timer før ønsket innsovning, og dosen bygges langsomt opp over mange uker.

De to blodtrykksmidlene lisinopril (ACEhemmer) og kandesartan (angiotensin II-reseptorhemmer) har vært mye brukt i mange land de senere år, til tross for at effekten bare er dokumentert i én god studie for hvert medikament $(6,7)$. Særlig kandesartan har lite bivirkninger og få kontraindikasjoner sammenliknet med de fleste andre aktuelle medikamenter. Nyreskade kan forekomme, især hvis pasienten samtidig bruker ikke-steroide antiinflammatoriske midler (NSAID).

De siste årene har det kommet studier som viser at injeksjoner med botulinumtoksin i muskulatur rundt hodet og i nakken kan ha en gunstig effekt ved såkalt kronisk migrene (8). Effekten er moderat, og det bør forsøkes kun hvis andre tiltak (forebyggende tablettbehandling, eventuelt medikamentavvenning ved mistanke om medikamentoverforbrukshodepine) har vært forsøkt. Det bør administreres av lege som har fått opplæring i bruk av medikamentet.

Betablokkerne fås på vanlig blå resept på indikasjonen migrene. For topiramat kan spesialist søke om refusjon på individuelt grunnlag når alle forhåndsgodkjente medikamenter er utprøvd. Gabapentin kan utskrives på blå resept for kroniske smerter, noe som kan være relevant for en del migrenepasienter. Øvrige medikamenter fås ved denne indikasjonen på hvit resept.

\section{Medikamentvalg}

Det er få studier der man har sammenliknet effekten av to ulike medikamenter, og ingen av medikamentene kan med sikkerhet sies å være mer effektivt enn et annet. Valget av medikament vil derfor avgjøres av grad av kunnskapsgrunnlag, kontraindikasjoner, bivirkninger, enkelhet i bruk og pris. Dessuten bør man kjenne pasienten så godt at man kan ta med i betraktningen gunstige effekter på eventuelle komorbide tilstander. For eksempel velger man et blodtrykksmedikament hvis pasienten har forhøyet blodtrykk, betablokker dersom det er takykardi eller essensiell tremor, et antidepressiv ved depresjon, og særlig amitriptylin hvis det er betydelige søvnvansker og utbredte kroppssmerter (fibromyalgi). Valproat kan være et naturlig valg hvis pasienten også har betydelig stemningslabilitet, og topiramat ved overvekt.

Mange pasienter vil være kvinner i fertil alder. Ingen av de forebyggende medikamentene anbefales til gravide (9), og man bør informere om at forebyggende behandling bør seponeres når graviditet planlegges, eller så snart som mulig når graviditet mistenkes. Valproat er teratogent $\mathrm{i}$ betydelig grad og bør unngås i det lengste hos fertile kvinner.

\section{Oppfølging}

Dersom det ifølge hodepinedagboken ikke er effekt av en vanlig dose i løpet av et par måneder, og det samtidig ikke er plagsomme bivirkninger, bør man forsøke høyere dose i minst en måned. Dersom man så konkluderer med at det ikke er noen effekt, er det vanlig å tilråde gradvis nedtrapping til seponering. Etter et opphold kan man forsøke et nytt medikament. Seponerer man på grunn av bivirkninger, bør man ikke starte et nytt behandlingsforsøk med et annet medikament før bivirkningene har gitt seg helt. Alle pasienter med betydelige migreneplager bør få tilbud om å forsøke minst tre ulike forebyggende medikamenter før man gir opp slik behandling.

\section{Lars Jacob Stovner (f. 1953)}

er professor i nevrologi ved Norges teknisknaturvitenskapelige universitet og overlege ved Avdeling for nevrologi og klinisk nevrofysiologi, St. Olavs hospital. Han er leder for Nasjonalt kompetansesenter for hodepine og også leder for Institutt for nevromedisin, Norges teknisknaturvitenskapelige universitet.

Forfatter har fylt ut ICMJE-skjemaet og oppgir følgende interessekonflikter: Han har mottatt midler fra Pfizer for å delta på et møte i New York om utvikling av legemidler for migrene. Instituttet har mottatt midler fra AstraZeneca til egeninitiert migrenestudie. 


\section{Erling Tronvik (f. 1970)}

er nevrolog ved Avdeling for nevrologi og klinisk nevrofysiologi, St. Olavs hospital. Han er postdoktor ved Nasjonalt kompetansesenter for hodepine og Institutt for nevromedisin, Norges teknisk-naturvitenskapelige universitet.

Forfatter har fylt ut ICMJE-skjemaet og oppgir ingen interessekonflikter.

\section{Knut Hagen (f. 1964)}

er spesialist i nevrologi og professor ved Norges teknisk-naturvitenskapelige universitet. Hans hovedstilling er tilknyttet Nasjonalt kompetansesenter for hodepine, med bistilling som overlege ved Avdeling for nevrologi og klinisk nevrofysiologi, St. Olavs hospital.

Forfatter har fylt ut ICMJE-skjemaet og oppgir følgende interessekonflikter: Han er medlem av Allergan Advisory Board.

\section{Litteratur}

1. Linde M, Stovner LJ, Zwart JA et al. Time trends in the prevalence of headache disorders. The NordTrondelag Health Studies (HUNT 2 and HUNT 3). Cephalalgia 2011; 31: 585-96.

2. Dahlöf C, Linde M, Linton-Dahlöf P. Migrän. Kliniska aspekter. Lund: Studentlitteratur; 2003

3. Evers S, Afra J, Frese A et al. EFNS guideline on the drug treatment of migraine-revised report of an EFNS task force. Eur J Neurol 2009; 16: $968-81$.

4. Olesen J, Bousser M-G, Diener H-C et al. red. The International Classification of Headache Disorders, 2nd Edition. Cephalalgia 2004; 24 (suppl1): $1-160$.

5. Hagen K, Albretsen C, Vilming ST et al. Management of medication overuse headache: 1-year randomized multicentre open-label trial. Cephalalgia 2009; 29: $221-32$

6. Schrader H, Stovner LJ, Helde G et al. Prophylactic treatment of migraine with angiotensin converting enzyme inhibitor (lisinopril): randomised, placebo controlled, crossover study. BMJ 2001; 322: 19-22.

7. Tronvik E, Stovner LJ, Helde G et al. Prophylactic treatment of migraine with an angiotensin II receptor blocker: a randomized controlled trial. JAMA 2003; 289: 65-9.

8. Dodick DW, Turkel CC, DeGryse RE et al. OnabotulinumtoxinA for treatment of chronic migraine: pooled results from the double-blind, randomized, placebo-controlled phases of the PREEMPT clinical program. Headache 2010; 50: 921-36.

9. Hagen K, Stovner LJ. Migrenebehandling ved graviditet og amming. Tidsskr Nor Lægeforen 2006; 126: 3107-9.

Mottatt 21.12. 2011, første revisjon innsendt 4.1. 2012, godkjent 22.3. 2012. Medisinsk redaktør Kristin Viste. 